ВИХОВАННЯ ШКОЛЯРІВ У ПОЗАШКІЛЬНИХ ОСВІТНІХ ЗАКЛАДАХ ЗАСОБАМИ ХОРЕОГРАФІЧНОГО МИСТЕЦТВА (НА ПРИКЛАДІ ПАЛАЦУ УЧНІВСЬКОЇ МОЛОДІ МІСТА ЛУЦЬКА)

\title{
ARTISTIC AND AESTHETIC EDUCATION OF CHILDREN'S IN HOUSES OF CREATIVITY BY MEANS OF CHOREOGRAPHIC ART (ON THE EXAMPLE OF THE PALACE OF STUDENT YOUTH OF LUTSK)
}

у статті висвітлюється проблема виховання школярів засобами хореографічного мистецтва у позашкільних освітніх закладах. Автор розглядає хореографрічне мистецтво як ефрективний засіб активізації процесу естетичного виховання школярів формування їх художнього світосприймання, осягнення прекрасного в мистецтві та житті, виховання художньої культури, творчого й емоційного ставлення до музики і мистецтва танцю. Розглядаються основні завдання, які вирішує педагог-хореограф, знайомлячи дітей з мистецтвом танцю у позашкільних освітніх закладах.

Роль і зміст художньо-естетичного виховання дітей засобами хореографрії у позашкільних освітніх закладах, зорієнтованих на культурологічне навчання і виховання, в організації художньо-естетичної діяльності школярів у статті чітко сфрормульовані і обгрунтовані. Заняття хореографрією стають для школярів засобом пізнання прекрасного, прилучення їх до скарбниці світової танцювальної творчості. Саме тому метою організації хореографрічної діяльност школярів у позашкільних освітніх закладах $€$ виховання у них художніх смаків, естетичних почуттів і важливих духовних якостей.

Виховний потенціал хореографрічного мистецтва бачиться автором в творчій атмоссрері занять, позитивному тонусі навчання танцю, що забезпечує активізацію широкої сорери естетичної думки, художньої уяви, франтазії, власної духовної потреби у мистецькому самовираженні. Основне завдання художньо-естетичного виховання засобами хореографрічного мистецтва автор вбачає у вихованні здатності дитини емоційно сприймати, відчувати, естетично оцінювати мистецтво танцю і передавати його красу у різних ї̈ проявах засобами танцювальних рухів.

Стаття знайомить нас 3 організацією освітнього процесу в Луцькому палаці учнівської молоді, освітньою роботою дитячих хореографрічних колективів.

Активна фестивально-кончертна діяльність хореографрічних колективів, висока майстерність їх учасників, яскраве розмаїmтя хореографрічних постановок забезпечують їм широку популярність не тільки на Волині, а й поза ї межами і за кордоном.

Ключові слова: виховання, естетична діяльність, танець, репертуар, хореогра- фрія, хореограсрічне мистецтво, художня культура.

The article highlights the problem of artistic and aesthetic education of schoolchildren by means of choreographic art. The author considers choreographic art as an effective means of enhancing the process of aesthetic education of schoolchildren, the formation of their artistic perception of the world, the comprehension of the beautiful in art and life, the upbringing of artistic culture, and the creative emotional attitude to music and the art of dance. The main tasks that are solved by the teacher-choreographer, introducing children to the art of dance in out-of-school educational institutions, are considered.

The role and content of artistic and aesthetic education of children by means of choreography in out-of-school educational institutions focused on cultural studies and education, the organization of artistic and aesthetic activities of schoolchildren in the article are clearly formulated and justified. Classes of choreography become for schoolchildren a means of knowing the beautiful, introducing them into the treasury of world dance creativity. That is why the goal of organizing choreographic activities of schoolchildren in out-ofschool educational institutions is to educate them in artistic tastes, aesthetic feelings and important spiritual qualities.

The author sees the upbringing potential of choreographic art in the creative atmosphere of classes, the positive tone of dance training, and activates a wide range of aesthetic thought, artistic imagination, fantasy, and his own spiritual need for artistic expression. The author sees the main task of artistic and aesthetic education by means of choreographic art in the upbringing of the child's ability to emotionally perceive, feel, esthetically evaluate the art of dance and convey its beauty in its various manifestations by means of dance movements.

The article introduces us to the organization of the educational process in the Lutsk Palace of students, the educational work of children's choreographic groups.

The active festival and concert activities of the choreographic groups, the high skill of the participants, the striking variety of choreographic performances, make them widely known not only in Volyn, but also abroad and abroad.

Key words: upbringing, aesthetic activity, dance, repertoire, choreography, choreographic art, art culture.
Постановка проблеми в загальному вигляді. Цілісний і гармонійний розвиток особистості, яка тонко відчуває красу, гармонію, духовність і благородство, неможливо уявити без ії естетичної вихованості. Художньо-естетичне виховання - це формування естетичного ставлення до дійсності, орієнтації особистості у світі естетичних пріорите- тів, здатності до естетичного сприймання і переживання мистецтва, художньо-естетичної творчості.

Одним із найважливіших засобів естетичного виховання молоді є мистецтво. Мистецтво - це одна з фрорм суспільної свідомості; вид людської діяльності, що відображає дійсність у конкретночуттєвих образах відповідно до певних естетичних 
ідеалів. Різні види мистецтва в умовах сучасного світу сприяють формуванню естетичної свідомості, що дозволяє конструювати, створювати, будувати свій життєвий шлях для кожної окремої людини з погляду краси і досконалості [1, с. 118].

Надзвичайно важливим засобом формування естетичного світосприймання, духовного світу і художньої культури особистості є хореограсрічне мистецтво. Серед інших видів мистецтва хореографрічне вирізняється своєю універсальністю. Воно здатне засобами руху, пластики і музичної інтонації передати внутрішній світ людини, її емоції та переживання, картини суспільних подій, рух у будь-яких його виявах, може вільно перенести нас у минуле, сучасне і майбутнє.

Аналіз останніх досліджень і публікацій. Виховна фрункція хореографрічного мистецтва досліджувалась Е. Абдулліною, Р. Акбаровою, Б. Асаф'євим, Л. Богатковою, А. Верещагіною, Н. Ветлугіною, Д. Кабалевським, І. Мойсеєвим, О. Радиновою, К. Тарасовою, В. Шпак та ін. Розробці проблем естетичного виховання дітей засобами різних видів мистецтв у позашкільних освітніх закладах присвятили свої праці Г. Березова, Л. Бондаренко, А. Тараканова та ін.

Виділення не вирішених раніше частин загальної проблеми. Важливість проблеми виховання школярів засобами хореографрічного мистецтва сьогодні зумовлена такими суперечностями: між необхідністю фрормування гуманістичного світогляду, духовності і моральності молодого покоління - майбутнього нашого суспільства - і сучасним соціокультурним середовищем, яке нерідко пропагує, особливо серед молоді, антигуманну ідеологію, бездуховність, примітивні зразки сучасного розважального мистецтва; між завданням школи в умовах трансорормації духовних ідеалів і потреб, девальвації моральних і естетичних цінностей формувати у школярів гуманістичні ідеали і реальним сучасним рівнем їх сорормованості; між потребами школярів у пошуках ціннісних орієнтацій, сенсу життя, можливостей власної творчої самореалізації і недостатнім рівнем цілеспрямованої роботи закладу загальної середньої освіти та позашкільних освітніх закладів у цьому напрямі.

Мета статті - педагогічне осмислення теоретичних засад та методичних прийомів виховання особистості школяра засобами хореографрічного мистецтва (на прикладі Палацу учнівської молоді м. Луцька).

Виклад основного матеріалу. Відповідно до завдань Концепції Нової української школи та гуманітаризації шкільного життя зростає роль і значення художньо-естетичного виховання школярів як засобу формування їх духовного світу, морально-естетичних ідеалів, залучення дітей до різних видів художньо-творчої діяльності, організації їх культурного дозвілля [4].
Стимулювати хореографрічну діяльність школярів можуть такі фрактори: естетична привабливість діяльності; її позитивні мотиви; емоційне піднесення в процесі діяльності; романтичне забарвлення і емоційне єднання в процесі спільної творчості; ритм роботи; франтазія, творчість; цікаві ігрові моменти; позитивний результат діяльності; захопливі перспективи тощо.

Хореографрічне мистецтво своєю художньою довершеністю відображає красу дійсності в її узагальнених емоційно-конкретних фрормах. Істотна особливість хореографрічного мистецтва - його спрямованість на активне фрормування духовної і моральної сорери особистості, виховання їі евристичного мислення, художньо-естетичних орієнтацій, розвиток емоційно-естетичної чутливості.

Розкриваючи світ людських почуттів, хореографрічне мистецтво відтворює дійсність, утверджує певні погляди на життя, фрормує світогляд, емоційну, естетичну і моральну культуру. Воно не тільки розвиває розум і тіло, воно ушляхетнює почуття і їх естетичний вияв.

Мистецтво хореографії володіє величезними можливостями фрормування художньої культури школярів. Художня культура особистості - важлива складова частина її духовної культури. Вона передбачає розвиток широкої художньої ерудиції, чуттєво-емоційної сфери особистості, естетичної свідомості, почуттів, поведінки дитини в конкретній творчій діяльності, в процесі якої відбувається художнє становлення особистості, фрормування їі естетичного світогляду, естетичних суджень, спрямованості, естетичного ставлення до мистецтва, суспільного життя, людей і до самої себе.

Художня культура особистості виражається в такому: в естетичному відчутті прекрасного в мистецтві, в житті, побуті, стосунках, в праці людей; у знанні і розумінні суті естетичного в мистецтві; в естетичному мисленні; у художній ерудиції і грамотності; у здоровому естетичному смаку; в опануванні художньої спадщини минулого, українського народного мистецтва; в особистісному ставленні до сучасного мистецтва та художньої культури.

Сьогодні вагомою ланкою в процесі художньоестетичного виховання школярів $€$ позашкільна освіта, яка спрямовує свої зусилля на естетичне виховання підростаючого покоління засобами хореографічного мистецтва й розвиток інтелектуальних, творчих здібностей особистості дитини на основі надбань культури й мистецтва українського народу, народних традицій. Позашкільні навчальні заклади у своєму арсеналі мають усі можливості для художньо-естетичного виховання дітей та оволодіння основами високого художнього смаку, бажання займатися улюбленим видом мистецтва [5, c. 47].

Як зазначено в Законі України «Про позашкільну освіту» та в Державній національній 
програмі «Освіта (Україна XX1 століття)», позашкільне виховання і навчання спрямоване на забезпечення потреб особистості у творчій самореалізації, здобуття школярами додаткових знань, умінь, навичок відповідно до їх інтересів, інтелектуального і духовного розвитку, а також на підготовку до активної професійної та громадської діяльності [2].

Проблема організації освітнього процесу у позашкільних закладах відповідно до нових соціальних запитів і освітніх завдань охоплює широке коло питань, що стосуються виховання у молоді гуманістичних світоглядних уявлень і ціннісних художніх орієнтацій, збагачення емоційноестетичного досвіду, виховання культури почуттів і поведінки, розвитку загальних і художніх здібностей, естетичного смаку, фрормування суспільноестетичних ідеалів і морально-духовних якостей, організації змістовного дозвілля і культурного відпочинку школярів.

3 огляду на завдання гуманізації та гуманітаризації шкільного життя позашкільні заклади, що діють на Волині, особливу увагу приділяють естетичному вихованню учнів, масовому залученню молоді до художньо-творчої самодіяльності.

Найбільший позашкільний заклад Волинського регіону - Палац учнівської молоді. Його відвідує понад 3,5 тис. дітей. Освітній процес у Палаці спрямований на виховання освіченої, культурної, гармонійно розвиненої молодої людини, створення умов для повноцінного інтелектуального і духовного розвитку особистості кожного вихованця, підготовку його до майбутньої активної професійної діяльності в галузі мистецтва.

У Палаці учнівської молоді не лише розвивають юні таланти та обдарування, а й надають консультативну допомогу педагогам і батькам з сучасних проблемних питань навчання і виховання школярів.

При Палаці учнівської молоді сьогодні працює 6 народних та 5 зразкових художніх колективів.

Серед осередків, які здійснюють професійну хореографрічну підготовку дітей та молоді на Волині, провідне місце належить ансамблю народного танцю «Радість». Це творчий колектив дітей та молоді, в якому любов до хореографрічного мистецтва об'єднує понад 450 хлопчиків і дівчаток віком від 4 до 18 років. За високу виконавську майстерність, яскравий талант юних артистів, художню довершеність їх танцювального мистецтва у 1986 році ансамблю «Радість» було присвоєно звання «Зразковий художній колектив», а у 2005 році ансамбль отримав звання «Народний художній колектив».

Відомими в області та за ії межами є такі народні хореографічні колективи: ансамбль спортивного і бального танцю «Ритм», ансамбль сучасного танцю «Міраж», ансамбль спортивного танцю «Троянда».
Народний ансамбль бального танцю «Ритм» $€$ членом спілки громадських організацій спортивного танцю України. Серед його учасників $€$ кандидати в майстри спорту та першорозрядники зі спортивних танців.

Вихованці збагачують досвід практичної хореографрічної діяльності під час участі у різноманітних концертах, виступах, змаганнях, фрестивалях, творчих звітах. Про ефективність роботи 3 дітьми свідчать щорічні перемоги ансамблю у міських, обласних та всеукраїнських конкурсах, турнірах.

За час існування колектив здобув безліч перемог і має багато досягнень. Він чемпіон України серед команд-формейшн, фріналіст відкритого чемпіонату Європи в Італії, учасник фрінальної стадії чемпіонату світу в Німеччині, лауреат міжнародних фрестивалів у Польщі, Чехії, Болгарії, Молдові, Україні, багаторазовий переможець міжнародних та всеукраїнських змагань зі спортивних танців, володар кубку України. Народний ансамбль бального танцю «Ритм» неодноразово визнавався кращим дитячим колективом міста. У 2005 році наказом Міністерства освіти і науки, молоді та спорту України ансамблю спортивного і бального танцю «Ритм» присвоєно звання «Зразковий художній колектив», а у 2012 році почесне звання «Народний художній колектив».

Народний ансамбль сучасного танцю «Міраж»учасник культурних програм, телепередач, концертів, благодійних акцій, лауреат республіканських та міжнародних конкурсів та фрестивалів. Ансамбль неодноразово підкорював своїм мистецтвом глядачів Польщі, Болгарії та Німеччини.

Колектив динамічно розвивається, втілює яскраві ідеї, вражає глядачів багатством та розмаїттям костюмів та постановок.

За високі творчі досягнення та активну концертну діяльність ансамблю «Міраж» у 2006 році присвоєно почесне звання «Зразковий художній колектив», у 2011 році - звання «Народний художній колектив».

Народний ансамбль спортивного танцю «Троянда» нараховує понад 200 учасників. щороку колектив бере участь у понад 50 заходах, включаючи концерти та змагання. Ансамбль здійснює виїзди в різні міста України та за її межі. Вихованці «Троянди» $є$ фріналістами та призерами багатьох міжнародних змагань в Ольштині, Кракові, Любліні (Польща), Градець-Кралові (Чехія), Братиславі (Словаччина), Могильові (Республіка Білорусь), Кишиневі (Молдова), Москві (Росія).

У 2010 році колективу присвоєно звання «Народний художній колектив».

Палац учнівської молоді постійно поповнюється талановитою молоддю міста, допомагає сучасним школярам відкривати і розвивати свої таланти. Варіативність фрорм і методів проведення занять в хореографрічних колективах забезпечує 
стійкий інтерес його учасників до танцювального мистецтва. Дітей приваблює улюблена справа, безпосередня участь у концертних виступах, оглядах-конкурсах, фрестивалях, природне бажання виразити себе, виявити свій талант і цікаво провести дозвілля.

Вихованці хореографічних колективів, які навчились відчувати і розуміти красу мистецтва танцю, бачити прекрасне у власній мистецькій творчості і повсякденному житті, стосунках, людських почуттях, виростають інтелектуально і фрізично розвиненими, порядними людьми і в дорослому житті намагаються сприймати навколишній світ 3 любов'ю, зберігати і примножувати у власній життєдіяльності духовні та естетичні цінності, які прищеплювали їм педагоги.

Висновки. Узагальнюючи сучасні педагогічні концепції і підходи до організації процесу виховання школярів у позашкільних закладах освіти, можна стверджувати про важливе значення у цьому процесі хореографрічного мистецтва, яке розширює художньо-естетичний кругозір, розвиває творчі таланти і обдарування, фрормує духовність дитини. Естетична цінність хореографрічного мистецтва полягає не тільки в зовнішніх проявах краси і гармонії рухів та виражених в них почуттях. Це мистецтво дозволяє естетично сприймати красу людських відносин, вчинків, помислів людини. Художні образи, створені мистецтвом танцю, стабілізують внутрішню модель мислення і культури поведінки дитини, стають зразками для розуміння нею змісту і краси справжнього мистецтва та повноцінного людського життя.

\section{БІБЛІОГРАФІЧНИЙ СПИСОК:}

1. Газнюк Л.М., Могильова С.В., Салтан Н.М. Естетика: навч. посіб. для студ. гуманітарних спец. Київ : Кондор, 2011. 124 с.

2. Державна національна програма «Освіта (Україна XXI століття»). Київ : Райдуга, 1994. 61 с.

3. Зайцев $€$. Основи народно-сценічного танцю. Вінниця, 2007. 416 с.

4. Концепція Нової української школи. URL: https://mon.gov.ua/storage/app/media/news/\%D0\%9D \%D0\%BE\%D0\%B2\%D0\%B8\%D0\%BD\%D0\%B8/2018/ 12/12/11/20-11-2018rekviz.pdf.

5. Медвідь Т.А Хореографрічна культура в працях дослідників мистецької галузі. Проблеми та перспективи розвитку хореографрічного мистецтва в контексті вищої освіти України : матеріали II Всеук. наук-метод. конф., м. Херсон, 26 квіт. 2010 р. Херсон : ХДУ, 2010. С. 47-52. 